Marcin SKOBRTAL

Uniwersytet im. Adama Mickiewicza, Poznań

\title{
Stosunek partii nacjonalistycznych Polski, Republiki Czeskiej, Słowacji i Węgier do integracji europejskiej
}

Przystapienie Polski, Republiki Czeskiej, Słowacji i Węgier do Unii Europejskiej w 2004 r. było, jak i wciąż jest przedmiotem licznych debat na temat korzyści i kosztów przystapienia, a także wizji dalszych losów integracji europejskich. Pojawiają się one na scenie politycznej każdego z tych państw, zawarte są także w programach partii politycznych. Swój pogląd w tej sprawie wypowiadają także partie o orientacji nacjonalistycznej. Choć na ogół kojarzone są ze skrajną prawicą i niewielkim znaczeniem w polityce, to ich stosunek do integracji europejskiej ma szczególne znaczenie. Nacjonalizm jest bowiem ideą stojącą w dużej mierze do opozycji względem projektów jedności Starego Kontynentu, także w sferze podstawowych założeń (rola i miejsce narodu). Ponadto partie nacjonalistyczne okresowo cieszą się dość sporym poparciem (taka sytuacja miała miejsce w czasie wyborów do Parlamentu Europejskiego w 2009 r.), co może być symptomem pewnego kryzysu idei integracji. Celem niniejszego artykułu jest scharakteryzowanie stosunku partii nacjonalistycznych z wymienionych państw do Unii Europejskiej oraz próba określenia ich społecznego odbioru.

\section{Republika Czeska}

Partie o orientacji nacjonalistycznej są ugrupowaniami stosunkowo słabo obecnymi na czeskiej scenie politycznej. Większość z nich ma charakter marginalny, nie startując nawet w wyborach parlamentarnych. W latach dziewięćdziesiątych XX w. największe znaczenie miało Zjednoczenie dla Republiki-Republikańska Partia Czechosłowacji (czes. Sdružení pro republiku-Republikanská strana Českoslobvenska, SPR-RSČํ),

1 W latach 2001-2008 jako Republikanie Miroslava Sladka, czes. Republikáni Miroslava Sladka, RMS, powrót do starej nazwy po zjednoczeniu kilku ugrupowań republikańskich. 
partia łącząca postulaty nacjonalizmu, republikanizmu i populizmu, która w wyborach 1992 i 1996 wprowadziła swoich posłów do czeskiego parlamentu ${ }^{2}$. Potem jednak jej znaczenie zaczęło systematycznie spadać. Specyficzny charakter miała Czeska Partia Narodowo-Socjalistyczna (czes. Česká strana národně socialistická, ČSNS ${ }^{3}$ ), powstała w 2005 r. w wyniku odłączenia się części działaczy Czeskiej Partii Narodowo-Socjalistycznej (czes. Česká strana národně sociálni, ČSNS), istniejącej w różnych postaciach od 1897 r. Nowa partia łączyła w swoim programie eurosceptycyzm, patriotyzm oraz demokratyzm, podczas gdy jej poprzedniczka zawierała hasła nacjonalistyczne i socjalistyczne. W ostatnich latach coraz silniejsza jest także skrajnie radykalna, narodowo-socjalistyczna i nacjonalistyczna Partia Robotnicza (czes. Dělnická strana, DS), która została rozwiązana wyrokiem sądu w lutym 2010 r., ale zaraz potem jej działacze zaczęli działać w Robotniczej Partii Sprawiedliwości Społecznej (czes. Dělnická strana sociální spravedlnosti, DSSS). Ponadto hasła nacjonalistyczne pojawiają się także $\mathrm{w}$ programach następujących mniejszych ugrupowań: Partia Narodowa (czes. Národní strana, $\mathrm{NS}^{4}$ ), Czeski Ruch Jedności Narodu (czes. České hnutí za národní jednotu, ČHNJ), Zjednoczenie Narodowe (czes. Národní sjednocení, NSJ), Prawo i Sprawiedliwość (czes. Právo a spravedlnost, PaS) oraz Front Patriotyczny (czes. Vlastnecká fronta, VF).

W programie SPR-RSČ stosunek do integracji europejskiej wyznacza stanowcze opowiedzenie się za pełną suwerennością państwa i sprzeciw wobec porządku opartego o internacjonalizm. Utrata lub ograniczenie suwerenności prowadzi do osłabienia państwa, co z kolei naraża go na zdominowanie przez Niemcy. Ponadto partia opowiada się za silną rolą państwa w stosunkach międzynarodowych, które w tym ujęciu powinny być przede wszystkim stosunkami między równorzędnymi podmiotami, przede wszystkim bilateralnymi, opartymi na zasadzie wzajemności. To państwo powinno w jak najszerszym zakresie prowadzić swoją politykę międzynarodową, nie poddając się jakiemukolwiek dyktatowi, w tym dyktatowi mocarstw. Tym samym stosunek do Unii Europejskiej jest jed-

2 W 1996 r. osiągnęła najwyższy wyborczy wynik: 8,06\%.

3 Została zarejestrowana jako Czeska Partia Narodowo Socjalna 2005 (ČSNS 2005).

4 Partia występowała w wyborach w 2004 r. w ramach Koalicji Narodowej (czes. Národní koalice, NK), także w 2005 r. również współpracowała z innymi partiami o podobnej orientacji. 
noznacznie negatywny, ponieważ postrzegana jest ona jako zagrożenie dla państwa, jego suwerenności i gospodarki, a także języka i kultury, a zatem także zagrożenie dla narodu ${ }^{5}$.

Z powyższych założeń wynikają oceny i komentarze dotyczące integracji Republiki Czeskiej z Unią Europejską. Partia zdecydowanie negatywnie oceniała Traktat lizboński i konieczność jego podpisania przez prezydenta Vaclava Klausa, którego doceniono za wcześniejszy sprzeciw. Uważano, że Traktat ogranicza czeską suwerenność i jest końcem wolności, często przywoływano w tym kontekście koniec I Republiki w 1938 r., doszukując się przy tym licznych paraleli historycznych (m.in. tak odczytano naciski niemieckiego przedstawiciela na prezydenta V. Klausa) ${ }^{6}$. Podobnie też opisywano czeską prezydencję w UE w roku 2009, którą poczytywano za faktyczny dyktat niemiecko-francuski na podobieństwo konferencji w Monachium w 1938 r. ${ }^{7}$ Za dyktat i zaprzeczenie demokracji uznaje się również działanie Komisji Europejskiej, czego przykładem było przyjęcie dyrektywy dotyczącej cen energii elektrycznej ${ }^{8}$.

NS opowiada się za Europą państw narodowych, w której szanowana będzie demokracja, tożsamość narodowa i odrębność poszczególnych państw, natomiast stanowczo odrzuca wizję Europy jako federacji regionów. Poszanowanie państwowości powinno być jedną z naczelnych zasad polityki europejskiej. Republika Czeska winna zachować w pełni swoją suwerenność na arenie międzynarodowej, politykę zagraniczną prowadząc na zasadzie pełnej równości i bez jakichkolwiek wpływów i ograniczeń. Postuluje w związku z tym wystąpienie Republiki Czeskiej z UE.

Czeska Partia Narodowo-Socjalistyczna uważa członkostwo w UE za niekorzystne i godzące w interesy obywateli czeskich. Z tego też względu opowiada się za innym modelem integracji, znacznie swobodniejszym, opartym na europejskim systemie wartości. Najbardziej pożądanym kształtem takiej integracji byłoby stowarzyszenie wolnego handlu. Jedno-

5 Volebni program pro parlamentní volby 2010, http://www.republikani.com/program.htm (21.02.2010).

6 D. Kučera, PREZIDENT VÁCLAV KLAUS BYL PŘINUCEN PODEPSAT LISABONSKOU SMLOUVU, 5.11.2009, http://www.republikani.com/clanky/0195.html (21.02.2010).

7 Několik dnů českého předsednictví Evropské unie, 13.01.2009, http://www.republikani.com/clanky/0144.htm (21.02.2010).

8 I. Vlk, Korupce v EU, 19.07.2006, http://www.republikani.com/clanky/0014.htm (21.02.2010). 
cześnie ČSNS opowiada się za pełnym respektowaniem Europejskiej Karty Socjalnej ${ }^{9}$.

Partia Robotnicza, mająca charakter narodowo-socjalistyczny i nacjonalistyczny, domagała się w swoim programie wystapienia z Unii Europejskiej i sprzeciwia się jakiemukolwiek ograniczaniu suwerenności Republiki Czeskiej. Z tego też względu partia była przeciwko Traktatowi Lizbońskiemu, tworzeniu urzędu Prezydenta UE i innym działaniom zmierzającym do jej federalizacji. Postulowała całkowitą równość w stosunkach między państwami, bez dyktatu silniejszych państw, a także jak najlepsze stosunki z najbliższymi sąsiadami ${ }^{10}$.

Zjednoczenie Narodowe opowiada się za równorzędną współpracą ze wszystkimi państwami europejskimi, jednocześnie sprzeciwiając się tworzenia struktur federacyjnych, które zdaniem partii oznaczają zanik europejskich wartości. Z tego też względu Zjednoczenie postuluje wystąpienie z Unii Europejskiej jako zagrażającej czeskiemu narodowi i państwu. Ponadto NSJ nie wierzy w możliwość istnienia wielonarodowych państw, a w UE widzi zagrożenie w postaci biurokracji i ponadnarodowego monopolu. Integracja europejska jest akceptowana tylko w postaci Europy narodów, opartej na współpracy i dobrych stosunkach między suwerennymi państwami, za którymi optuje ta partia. Europa winna wrócić do jej chrześcijańskich i antycznych korzeni, w które wpisuje się także odrodzenie narodowe. Relacje z Niemcami mogą również mieć dobrosąsiedzki charakter pod warunkiem odstąpienia od chęci rewizji tzw. dekretów Benesza. Niedopuszczalne jest jakiekolwiek zmienianie powojennego status quo oraz ingerencja w sprawy innych państw. Sprzeciw względem prób tworzenia europejskiego „superpaństwa” były przyczyną braku zgody na europejską konstytucję europejska i udział w wyborach do Parlamentu Europejskiego. Traktat lizboński był postrzegany podobnie, jako działanie ,syjonistów", a moment jego podpisania uznawano za koniec suwerenności. Przywoływano tutaj także kwestię roszczeń Niemców sudeckich ${ }^{11}$.

9 PROGRAM ČESKÉ STRANY NÁRODNĚ SOCIALISTICKÉ, http://www.narsoc.cz/index_soubory/program.htm (27.02.2010).

${ }_{10}$ Program Dělnické strany, http://www.delnicka-strana.cz/index.php?option=com_content\&task=view\&id=74\&Itemid=103 (27.02.2010), Volební program Dělnické strany, http://volby.delnickelisty.cz/program (27.02.2010).

${ }^{11}$ Manifest Národního sjednocení, http://www.nsj.cz/manifest.htm (27.02.2010), Program strany Národni sjednoceni, http://www.nsj.cz/program.htm (27.02.2010), Stanoviska Národního sjednocení, http://www.nsj.cz/stanoviska.htm (27.02.2010). 
Programy innych mniejszych partii zapatrują się na kwestie integracji europejskiej w podobny sposób. $\breve{C} H N J$ ocenia wstappienie do UE negatywnie. Przy podpisywaniu międzynarodowych umów zwraca się uwagę na konieczność respektowania zasady równości oraz suwerenności państwa. Przedstawiciele państw winni kierować się tutaj przede wszystkim dobrem narodu ${ }^{12}$. Front Patriotyczny również postrzega członkostwo w Unii Europejskiej w kategoriach zniewolenia. Odmawia uznania Traktatu z Maastricht jako ograniczającego suwerenność państwa na rzecz „ponadnarodowej superbiurokracji i kapitału”, jednocześnie sprzeciwiając się pozbawianiu europejskich państw suwerenności. Partia natomiast opowiada się za Europą narodów, opartą na zbliżeniu i współpracy, a nie na hegemonii większych państw ${ }^{13}$. Natomiast narodowo-konserwatywna partia Prawo i Sprawiedliwość opowiada się za gospodarczą współpracą suwe-

Wykres 1. Wyniki wyborcze (wybory parlamentarne i do Parlamentu Europejskiego) partii nacjonalistycznych w Republice Czeskiej na początku XXI w.

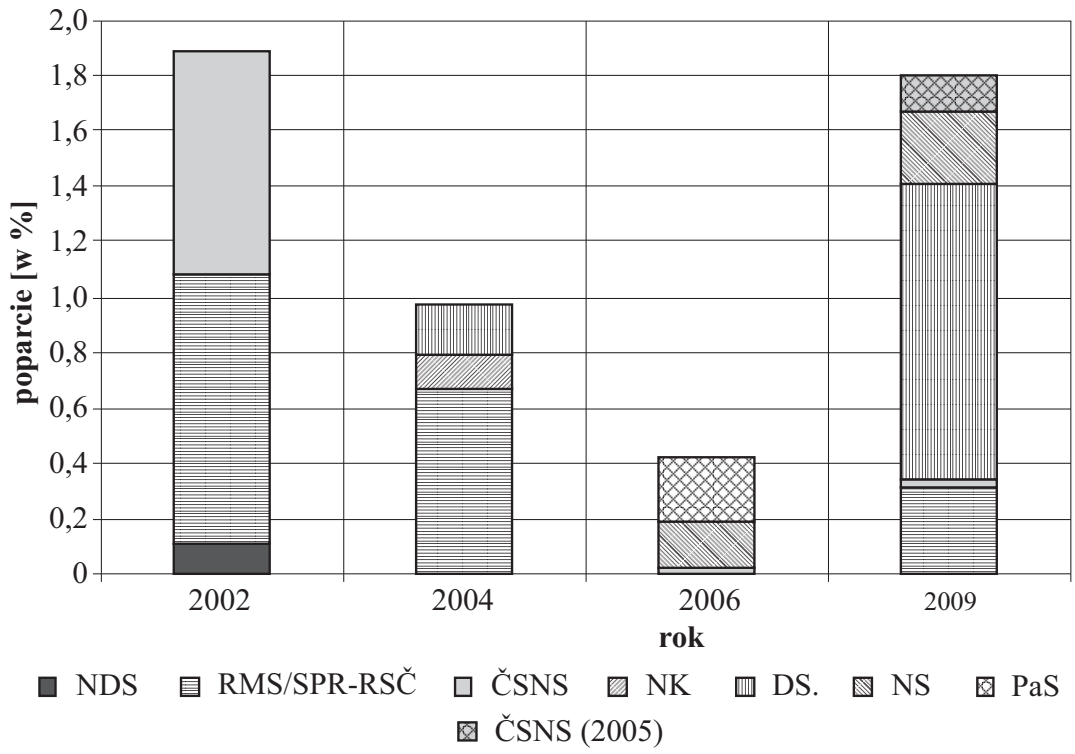

Źródło: Český Statistický Úřad, http://volby.cz/ (22.02.2010).

12 PROGRAM Českého hnuti za národni jednotu, http://www.chnj.wz.cz/ (27.02.2010).

13 Akčni program Vlastenecké Fronty, Vlastnecká Fronta, http://www.vlasteneckafronta.cz/program.html\#10 (21.02.2010). 
rennych państw, tym samym sprzeciwiając się idei europejskiego „superpaństwa”. Opowiada się przy tym za współpracą z Polską i Słowacją ${ }^{14}$.

Podsumowując powyższy przegląd można zauważyć, iż stosunek do UE wśród wszystkich opisanych partii jest dość zbliżony. Wszystkie one oceniają ją jednoznacznie negatywnie, często postulując nawet wystąpienie z UE. Za największe zagrożenie uważa się projekty federalizacji oraz związana z tym dominacja dużych państw, w szczególności Niemiec. Często w tym kontekście przywoływane są doświadczenia historyczne, szczególnie układ monachijski i koniec Republiki Czechosłowackiej w latach 1938-1939. Przeciwwagą dla takich tendencji ma być współpraca suwerennych państw narodowych, często w szczególności słowiańskich lub środkowoeuropejskich.

Wyniki wyborcze wszystkich partii o orientacji nacjonalistycznej (razem 1-2\%) pokazują, że ich udział w czeskim systemie politycznym ma marginalne znaczenie. Warto jednak zauważyć, że o ile do 2006 r. ich poparcie systematycznie spadało (do poniżej $0,5 \%$ ), o tyle w wyborach do Parlamentu Europejskiego wzrosło ono ponad czterokrotnie. Zmieniła się także dominująca w tym bloku partia, którą stała się Partia Robotnicza

Wykres 2. Poparcie społeczeństwa czeskiego dla czlonkostwa w Unii Europejskiej

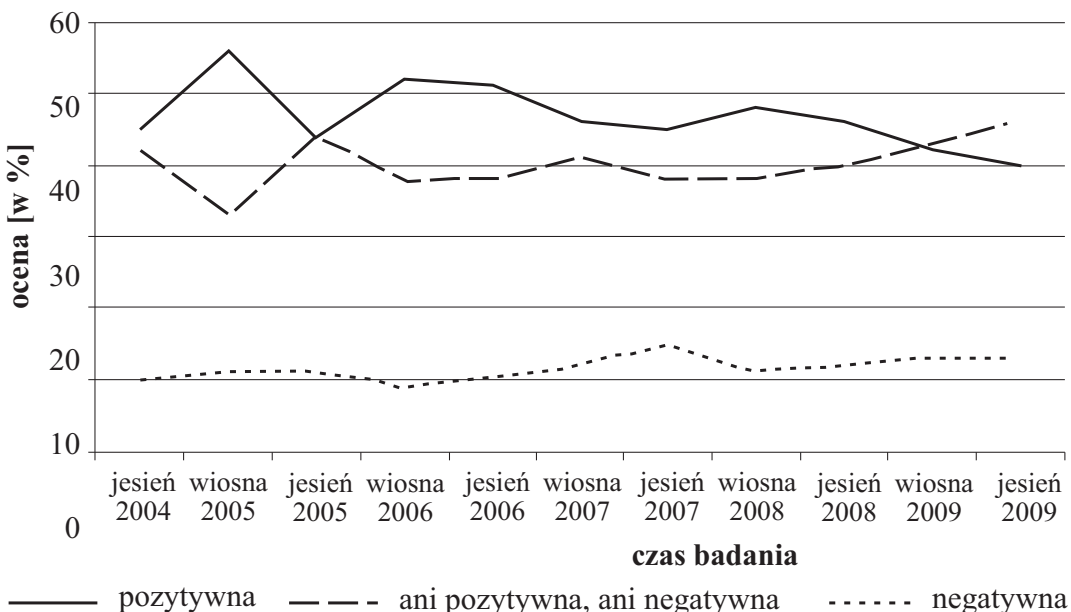

Źródło: European Comission - Public Opinion, http://ec.europa.eu/public_opinion/standard_en.htm (23.02.2010).

14 Právo a Spravedlnost záštita tradičnich hodnot, http://www.pas-strana.cz/hodnoty.php (27.02.2010). 
w miejsce ugrupowania Miroslava Sladka. Te wahania, jakkolwiek nie związane z uzyskaniem miejsca w parlamencie, wskazywać mogą, iż kryzys gospodarczy oraz sprawa podpisania Traktatu Lizbońskiego przez eurosceptycznego prezydenta Vaclava Klausa mogły wpłynąć na niewielką część społeczeństwa o skrajnych poglądach. Tendencję do bardziej krytycznego spojrzenia na Unię Europejską potwierdzają również badania Eurostatu dotyczące członkostwa Republiki Czeskiej w UE. W 2008 r. można zaobserwować wzrost ocen negatywnych oraz neutralnych (ani pozytywne, ani negatywne), a na początku 2009 r. liczba tych drugich przewyższyła liczbę pozytywnych. Zestawiając obie statystyki należy jednak stwierdzić, że mimo wzrostu nastrojów eurosceptycznych, skrajnie antyeuropejskie hasła nie zyskują poparcia w społeczeństwie czeskim.

\section{Słowacja}

Główną partią nacjonalistyczną na słowackiej scenie politycznej jest Słowacka Partia Narodowa (słow. Slovenská Narodná Strana, SNS), powołująca się na korzenie sięgające roku $1871^{15}$. Jest to dość istotna partia na słowackiej scenie politycznej, zdobywająca w różnych okresach 2-15\% głosów, w latach 1992-1998 i 2006-2010 uczestnicząca w koalicji rządzącej. W 2009 r. jeden jej kandydat został deputowanym w Parlamencie Europejskim. W 2002 r. doszło do rozłamu w łonie SNS, w wyniku czego powstała Prawdziwa Słowacka Partia Narodowa (słow. Pravá slovenská narodná strana, PSNS). Rozłam trwał do 2006 r. Poza nią orientację narodową prezentują także dwie partie o marginalnym znaczeniu: Słowacka Jedność Narodowa (słow. Slovenská narodná jednota, SNJ) i Słowacka Partia Ludowa (słow. Slovenská l'udová strana, SLS), nawiązująca do działającej w okresie międzywojennym partii ks. Andreja Hlinki, Zjednoczona Słowacka Partia Narodowa (słow. Zjednotená slovenská narodná strana, ZSNS) oraz Słowacka Koalicja Narodów - Słowacka Wzajemność (słow. Slovenská národná koalícia - Slovenská vzájomnost', SLNKO).

W opinii SNS Unia Europejska powinna być oparta na silnych, suwerennych państwach, a nie na regionach. Partia uznaje przystąpienie do UE za realizację celu postawionego w 1993 r. Słowacja jako państwo identyfi-

15 História Slovenskej Národnej Strany, http://www.sns.sk/modules.php?na$\mathrm{me}=$ Content\&pa $=$ showpage \&pid=134 (28.02.2010). 
kujące się z takimi wartościami, jak wolność, demokracja i prawa człowieka jest częścią europejskiego chrześcijańskiego kręgu kulturowego. Ponadto w wizji funkcjonowania Unii Europejskiej postuluje się decentralizację i dekoncentrację europejskich instytucji, a co za tym idzie przeniesienie ich do Bratysławy, jako mieszczącej się w geograficznym środku Europy. Miałby to być wyraz przeniesienia geopolitycznego środka kontynentu z zachodu do centrum. Ponadto domaga się uproszczenia zarządzania funduszami strukturalnymi oraz ograniczenia biurokracji w instytucjach europejskich. Na polu polityki zagranicznej w Unii Europejskiej SNS postulowała stworzenie wspólnej linii politycznej mniejszych państw UE, a także rozwój współpracy w Europie Środkowej oraz między państwami słowiańskimi. Stosunki z innymi państwami winny być przyjazne, ale także (w przypadku Węgier) oparte na rozwadze i wzajemności ${ }^{16}$.

Podobne założenia znalazły się także w programie sformułowanym w 2002 r., a więc na 2 lata przed przystąpieniem Słowacji do Unii Europejskiej. Uznano wówczas, iż względy geopolityczne i geostrategiczne przemawiają za pełną obecnością Słowacji w strukturach europejskich oraz udziale w europejskiej kulturze i cywilizacji, jednak integracja winna się opierać na suwerennych państwach, a nie modelu federalistycznym i centralistycznym. Akcesja do UE jest korzystna dla Słowacji, jakkolwiek partia zaznacza, że członkostwo musi uwzględniać także zabezpieczenie interesów państwa. O ile możliwa jest rezygnacja z części suwerenności, to nie można zrezygnować $\mathrm{z}$ tożsamości narodowej ${ }^{17}$.

W odróżnieniu do wielu innych partii nacjonalistycznych SNS pozytywnie odnosi się do Traktatu Lizbońskiego. Poparcie to opiera się na uznaniu konieczności dostosowywania UE do zmieniającej się rzeczywistości, w tym do nowych rozszerzeń, i realistycznym podejściu do kwestii suwerenności, która współcześnie rzadko kiedy może być pełna. Traktat jest uznawany za korzystny dla mniejszych państw, ponieważ daje im większą możliwość decydowania o sprawach UE. Popierane są wszelkie rozwiązania zwiększające poziom demokracji (np. działalność Parlamentu Europejskiego) oraz respektujące wolność państw, postuluje się także ograniczenie biurokracji. Jest to kierunek reform, które zdaniem poli-

16 VOLEBNÝ PROGRAM SLOVENSKEJ NÁRODNEJ STRANY. SME SLOVÁCI SLOVÁKOM SLOVENSKÚ VLADU, 2006, s. 38-42.

17 PROGRAM NÁRODNEJ OBNOVY. Pre volebné obdobie 2002-2006, Bratislava 2002, s. 19. 
tyków SNS są w UE konieczne. Nie ma natomiast akceptacji dla projektów przekształcenia UE w państwo federalne, do którego zdaniem SNS zmierzają największe frakcje w PE, ponadto $\mathrm{w}$ dobie globalizacji struktury europejskiej są uznawane za potrzebne. Europa winna szanować odrębność poszczególnych narodów i być oparta na państwach narodowych oraz wartościach chrześcijańskich. Ponadto za wyzwania stojące na drodze europejskich polityków uznawane są: globalizacja, problemy demograficzne, zagrożenia związane z rozwojem techniki, stan środowiska naturalnego ${ }^{18}$.

Inne, znacznie mniejsze partie o orientacji narodowej zajmują stanowisko zbliżone do SNS, przede wszystkim akcentują konieczność zachowania pełnej suwerenności. Słowacka Jedność Narodowa w swoim programie opowiada się za podporządkowaniem współpracy w ramach

Wykres 3. Poparcie wyborcze (wybory parlamentarne i do Parlamentu Europejskiego) dla Słowackiej Partii Narodowej

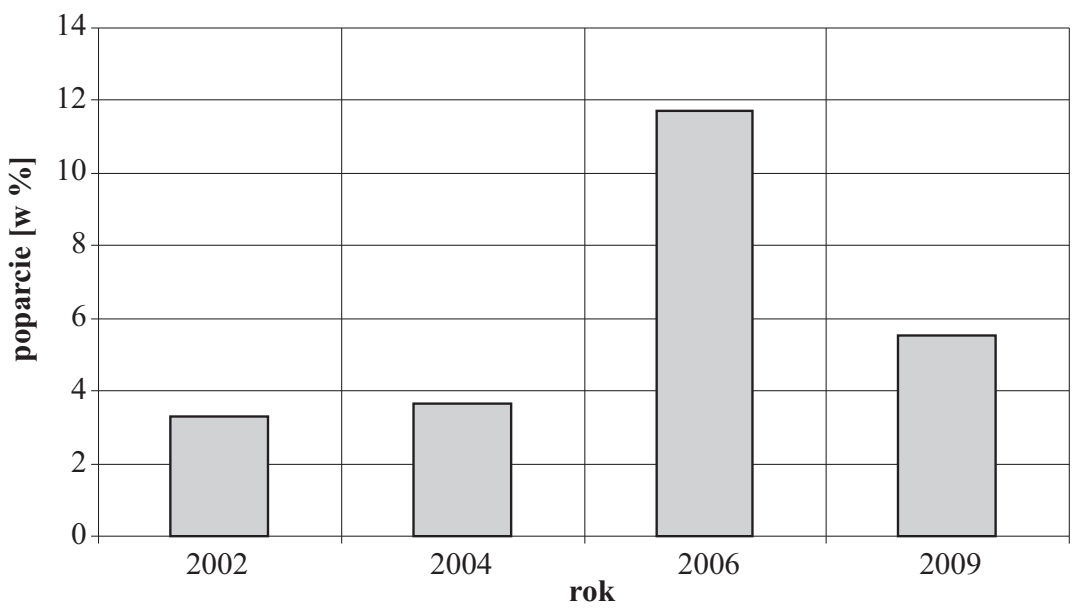

Źródło: Štatistický Úrad Slovenskej republiky, http://www.statistics.sk/struk/volby.htm (24.02.2010).

18 Stanowiska takie prezentują różni politycy SNS, np. Jozef Rydlo, deputowany do Rady Narodowej: L. Kováčik, Jozef Rydlo: Európska únia sa nachádzav duchovnej krize, 14.01.2009, http://www.sns.sk/modules.php?name=News\&file=article\&sid=1438\&mo$\mathrm{de}=\&$ order $=0 \&$ thold $=0$ (28.02.2010); Jozef Rydlo: Akú Európu chceme a prečo?, 23.11.2008, http://www.sns.sk/modules.php?name=News\&file=article\&sid=1345\& mode $=\&$ order $=0 \&$ thold $=0$ (28.02.2010); Jozef Rydlo: Prečo volit'vo vol'bách do Európskeho parlamentu práve SNS?, 19.05.2009, http://www.sns.sk/modules.php?na$\mathrm{me}=$ News $\&$ file $=$ article $\&$ sid $=1659 \&$ mode $=\&$ order $=0 \&$ thold $=0 \quad(28.02 .2010)$. 
struktur europejskich pełnej suwerenności państwa oraz równorzędności i wzajemności w stosunkach z innymi państwami. Domaga się również prawa weta w sprawach, które tyczą się Słowacji. Słowacka Partia Ludowa także opowiada się za Europą suwerennych państw narodowych, a nie tworzeniem państwa europejskiego, określanego tutaj mianem totalnego.

Cechą charakterystyczną Słowackiej Partii Narodowej na tle innych, podobnych ugrupowań w Europie Środkowej, była akceptacja członkostwa Słowacji w Unii Europejskiej. Co prawda i tutaj akcentowano sprzeciw względem federalizacji i potrzebę ochrony tożsamości narodowej oraz państwowości, jednak uznano, że członkostwo w UE jest korzystne i nie rodzi zagrożeń. Innym wyróżnikiem SNS jest także ostry konflikt z węgierskimi ugrupowaniami nacjonalistycznymi, związany z sytuacją mniejszości węgierskiej na południu Słowacji. Konflikt ten przeniósł się także do Parlamentu Europejskiego.

Z uwagi na fakt, iż poza SNS, wszystkie pozostałe formy mają znikome poparcie wyborcze, analizę poparcia społecznego można ograniczyć do tego jednego ugrupowania. Należy tutaj zaznaczyć, że w wyniku wspomnianego wyżej podziału, w wyborach uczestniczyły zarówno SNS, która

Wykres 4. Poparcie społeczeństwa słowackiego dla czlonkostwa w Unii Europejskiej

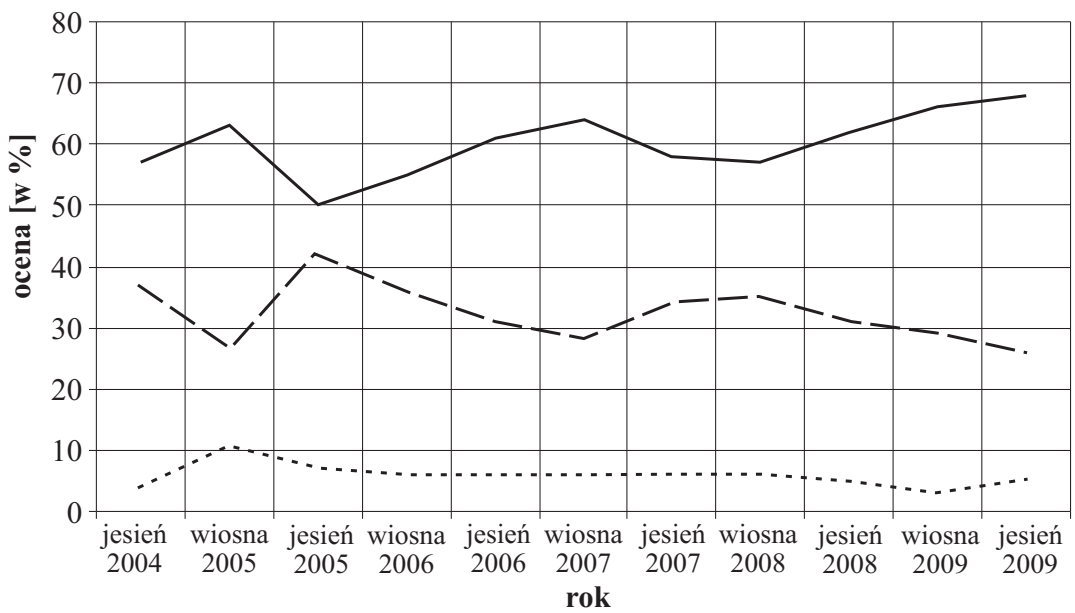

pozytywna - - - ani pozytywna, ani negatywna ...... negatywna

Źródło: European Comission - Public Opinion, http://ec.europa.eu/public_opinion/standard_en.htm (23.02.2010). 
uzyskała poparcie 3,32\%, jak i PSNS z poparciem 3,65\% ${ }^{19}$. Żadna nich nie dostała się wówczas do parlamentu, ale łączny wynik $(6,97 \%)$ już by na to pozwolił. W 2004 r. obie partie w wyborach do Parlamentu Europejskiego startowały jako koalicja. Poparcie dla SNS było stosunkowo zmienne, choć na tyle wysokie, by dać możliwość działaczom tej partii wpływu na politykę państwa. Umiarkowanie pozytywny stosunek do integracji odpowiada wyraźnie proeuropejskim tendencjom w słowackim społeczeństwie, co może pomagać SNS uzyskać w miarę szeroki elektorat.

\section{Węgry}

Nacjonalistyczny charakter na węgierskiej scenie politycznej mają obecnie dwie współpracujące ze sobą partie. Pierwszą z nich jest Węgierska Partia Sprawiedliwości i Życia (węg. Magyar Igazság és Élet Pártja, MIÉP), powstała w 1993 r. z grupy byłych opozycjonistów o narodowej, skrajnie prawicowej orientacji. Partia, choć od tego momentu startowała we wszystkich wyborach, tylko raz zdołała nieznacznie przekroczyć próg wyborczy. Drugą partią jest natomiast Ruch na rzecz Lepszych Węgier (węg. Jobbik Magyarországért Mozgalom), który powstał w 2003 r. Obie partie nawiązały współpracę w 2005 r.

Ruch na Rzecz Lepszych Węgier postuluje, aby Unia Europejska była i wciąż pozostawała silną i wielokulturową wspólnotą suwerennych państw. W związku z tym partia proponuje negocjacje i referendum w sprawie konstytucji europejskiej, współpracę między państwami regionu oraz ochronę europejskich wartości, szczególnie przeciwko wpływom amerykańskim $^{20}$. Krytycznie są oceniane wszystkie działania Unii Europejskiej, które mogłyby być niezgodne z interesami węgierskimi. Tak interpretowano zapewnienia gwarancji nierewidowania tzw. dekretów Benesza dla Republiki Czeskiej. Była ona wówczas postrzegana jako dążąca do stworzenia ponadnarodowego państwa, które nie respektuje praw człowieka, a w szczególności mniejszości ${ }^{21}$.

19 Vol'by do NR SR 2002, http://www.statistics.sk/volby2002/webdata/slov/tab/ tab3.htm (28.02.2010).

${ }^{20}$ Gabor Bethlen National ProgrammeJobbik-The Movement For A Better Hungary. New Power - New Radicalism, s. 4.

21 Z. Várkonyi, Jobbik about the EU.S.S.R - Czech pact, 5.11.2009, http://www.jobbik.com/europe-news/3127.html (25.02.2010). 
W programie na wybory w 2010 r. Jobbik ponownie opowiada się za Europą Narodów, podkreślając, że w przypadku, gdyby kierunek integracji nie byłby zgodny z węgierskim interesem, należy zrezygnować z UE, która nie jest tożsama z Europa, bowiem do tej ze względu na historię i wartości Węgry należały od zawsze. Traktat lizboński nie jest uważany za niezgodny z naturalnym rozwojem kontynentu, sankcjonujący przewagę większych państw nad mniejszymi. Krytykowane jest przyjęcie całości traktatu bez wyłączeń, jakie uzyskały Wielka Brytania, Polska czy Republika Czeska. Ponadto Jobbik zarzuca Unii Europejskiej nierozwiązanie kwestii mniejszości narodowych, deficyt demokracji, korupcję przy dystrybucji funduszy strukturalnych oraz niedostateczny poziom ochrony środowiska naturalnego. Ponadto partia domaga się także większego zaangażowania w rozwiązanie problemów mniejszości węgierskich w państwach sąsiadujących $\mathrm{z}$ Węgrami ${ }^{22}$.

Stanowisko partii względem Unii Europejskiej zawiera się też w deklaracji politycznej powołanego na kongresie w Budapeszcie 24 października 2009 r. Sojuszu Europejskich Ruchów Narodowych, w skład którego weszły partie narodowe z Francji, Włoch, Szwecji i Belgii. We wspomnia-

Wykres 5. Poparcie wyborcze (wybory parlamentarne i do Parlamentu Europejskiego) dla węgierskich ugrupowań nacjonalistycznych na początku XXI w.

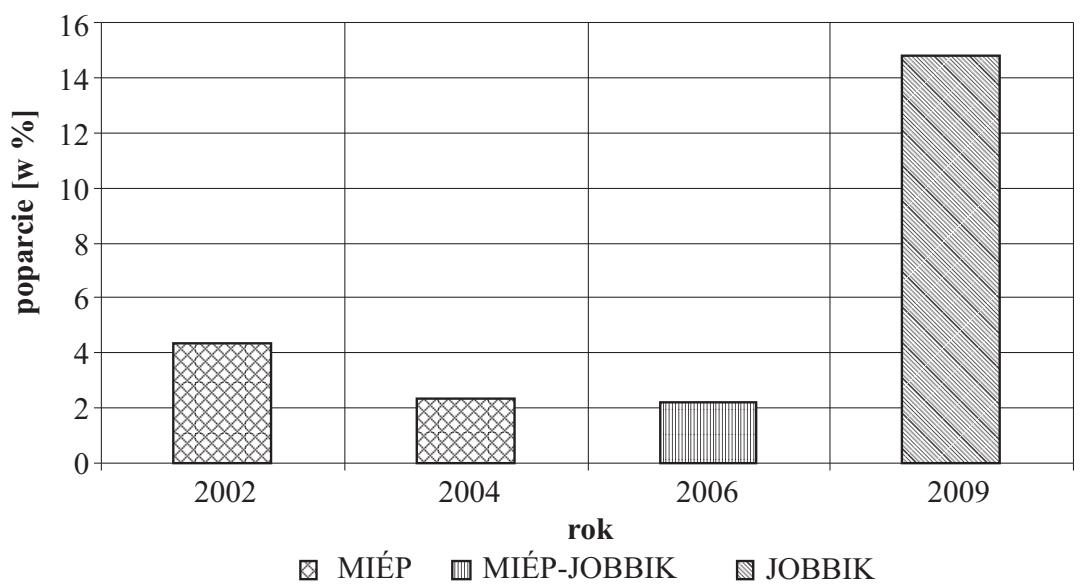

Źródło: Országosz Válsztási Iroda, http://www.valasztas.hu/en/ovb/index.html (28.02.2010).

${ }^{22}$ Radikális változás. A Jobbik országgyülési választási programjaa nemzeti önrendelkezésértés a társadalmi igazságosságért, s. 75-76. 
nym dokumencie odrzuca się tworzenie scentralizowanego europejskiego państwa na rzecz konfederacji wolnych, równych i suwerennych państw narodowych, które będą chronić prawa jednostek. Deklaracja zawiera także sprzeciw względem wszelkim formom totalitaryzmu, fundamentalizmu religijnego i imperializmu. Europa winna zaangażować się także w obronę rodziny, rozwiązanie problemów imigrantów oraz wspólną walkę z negatywnymi skutkami globalizacji. Sojusz ma być europartią na wzór innego rodzaju stronnictw w Parlamencie Europejskim, po jego utworzeniu podjęto rozmowy z ugrupowaniami narodowymi z Ukrainy, Hiszpanii, Portugalii, Litwy, Słowenii i Austrii. Jobbik odmawia natomiast współpracy z nacjonalistami słowackimi ze względu na ich antywęgierską działalność ${ }^{23}$.

Zdaniem MIÉP członkostwo w UE jest dla Węgier niekorzystne pod względem ekonomicznym i upośledza rozwój państwa. Jednocześnie partia jest zdania, że Unię Europejską czeka rychły koniec ${ }^{24}$.

Stosunek węgierskich partii narodowych do UE cechuje kilka elementów charakterystycznych. Pierwszym z nich jest sprzeciw względem globalizacji, która jest uważana za większe zagrożenie niż integracja europejska. Druga jest natomiast ocena działań UE pod kątem interesów ludności węgierskiej w ościennych państwach. Trzecią jest natomiast zwrócenie uwagę na aspekt gospodarczy i niekorzystny bilans korzyści, co może mieć związek z węgierskim kryzysem gospodarczym. Natomiast koncepcja Europy Narodów i oparcia integracji na wartościach, szczególnie na chrześcijaństwie jest charakterystyczne też dla innych państw regionu.

Wyniki wyborcze obu partii do 2009 r. były niewysokie, nie pozwalając na uzyskanie miejsca w parlamencie. Sporym zaskoczeniem był duży sukces partii Jobbik w wyborach do Parlamentu Europejskiego w 2009 r. Należy zwrócić uwagę, iż miał on miejsce w szczególnym dla Węgier okresie - państwo było pogrążone w kryzysie, w roku 2006 protesty na ulicach Budapesztu zachwiały stabilnością polityczną. Ta trudna

23 Bela Kovacs: Our geographical and historical heritage ties our country to Europe and Russia, Jobbik - The Movement for Better Hungary, http://www.jobbik.com/europe-news/3150.html (23.02.2010); AENM Press Conference in Brussels, Jobbik - The Movement for Better Hungary, http://www.jobbik.com/europe-news/3131.html (23.02.2010).

24 A rend programja a MIÉP szándékai, céljai, javaslatai, http://www.miep.hu/index.php?option=com_content $\&$ view $=$ article $\&$ id=46\&Itemid=55 (26.02.2010). 
sytuacja przekładała się na najbardziej krytyczny w całej Europie Środkowej stosunek do integracji europejskiej. Od jesieni 2006 r., a więc od wspomnianych protestów przeciw polityce rządu zaczęła spadać liczba ocen pozytywnych, natomiast wzrósł odsetek ocen negatywnych i neutralnych, które zaczęły dominować. Ponadto znaczenie może mieć konflikt związany z węgierską mniejszością na południu Słowacji, w którym doszło również do konfrontacji partii narodowych z obu państw.

\section{Wykres 6. Poparcie społeczeństwa węgierskiego dla czlonkostwa w Unii Europejskiej}

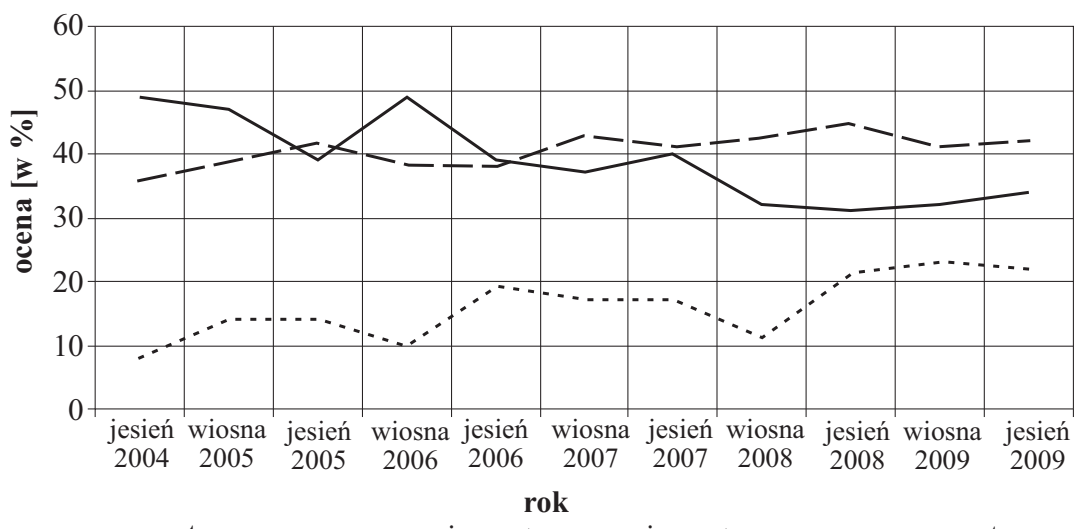

Źródło: European Comission - Public Opinion, http://ec.europa.eu/public_opinion/standard_en.htm (23.02.2010).

\section{Polska}

W Polsce najsilniejszą partią prezentującą orientację narodową jest Liga Polskich Rodzin, powstała w 2001 r. z połączenia kilku ugrupowań nacjonalistycznych (m.in. Stronnictwa Narodowego i Stronnictwa Narodowo-Demokratycznego). Jej ideologiczne korzenie odwołują się do przedwojennej Narodowej Demokracji i Obozu Wielkiej Polski oraz emigracyjnego Stronnictwa Narodowego. Wkrótce potem od partii zaczęły odłączać się mniejsze ugrupowania o podobnym programie. Ponadto istnieje kilka innych, znacznie mniejszych partii: narodowo-radykalne Narodowe Odrodzenie Polski czy Polska Wspólnota Narodowa.

Stanowisko Ligi Polskich Rodzin dotyczące integracji europejskiej wyraża książka Quo vadis Europo? członka Parlamentu Europejskiego, Macieja Giertycha, będącego zarazem jednym z głównych ideologów 
partii oraz synem Jędrzeja Giertycha, kształtującego polski nacjonalizm po II wojnie światowej. Pierwszym elementem postawy względem Unii Europejskiej jest sprzeciw wobec ,pruskiego imperializmu”, który zdaniem autora jest obecnie dominującym trendem integracji, przeciwnego do modelu tworzonego m.in. przez pochodzącego z zachodnich Niemiec Konrada Adenauera, który wyraźnie podkreślał chrześcijańskie korzenie Europy. M. Giertych powołuje się w tym miejscu na wcześniejsze próby opanowania Europy Środkowej, m.in. w czasie II i III Rzeszy. W kategoriach dążenia do hegemonii traktowane są także współczesne działania Niemiec w zakresie integracji europejskiej, m.in. projekt konstytucji europejskiej, wspólna waluta euro czy niemiecka prezydencja w UE. Różnego rodzaju działania niemieckie są tutaj postrzegane jako przygotowania do zdominowania Europy, w szczególności Środkowej. Drugim krytykowanym elementem jest „Europa regionów”, obecna w wizji Jeana Moneta. Jest to, zdaniem autora, zagrożenie nie tylko dla państwa, ale także i narodu, z tej też pozycji potępiane są działania zmierzające do decentralizacji władzy publicznej. Trzecim elementem wizji Europy jest cywilizacja, zaczerpnięta z myśli Feliksa Konecznego. Wspomniane wyżej działania Niemiec są uznawane za przejaw oddziaływania w tym państwie (a konkretnie w dawnych Prusach) cywilizacji bizantyńskiej, skupionej na państwie i autorytarnej. Tak też jest rozumiany obecny kształt UE. Tej cywilizacji przeciwstawiana jest cywilizacja łacińska, opierająca się na wolności, prawach jednostki i demokracji. Do cywilizacji łacińskiej należeć miała przedrozbiorowa Polska. Za zagrożenie dla współczesnej Europy uznawana jest ekspansja islamu ${ }^{25}$.

LPR krytykowała podpisanie Traktatu Lizbońskiego oraz wszelkie zmiany z tego wynikłe, uznając, iż jest to koniec wolności i narzucenie Polsce obcej zwierzchności ${ }^{26}$. Ponadto partia uważa, że Unia Europejska i jej polscy zwolennicy działają na korzyść polskiej gospodarki, czego dowodem była krytyka postanowień w sprawie redukcji emisji dwutlenku węgla ${ }^{27}$.

W programie ugrupowania Naprzód Polsko, tworzonego przez byłych członków Ligi Polskich Rodzin również pojawia się poparcie dla Europy

25 M. Giertych, Quo vadis Europo?, Bruksela 2009.

26 Stanowisko Zarzqdu Głównego Ligi Polskich Rodzin w sprawie wejścia w życie traktatu lizbońskiego, http://www.lpr.pl/?sr=!czytaj\&id=6751\&dz=kraj\&x=18\&pocz= 0\&gr= (27.02.2010); Liga Polskich Rodzin podjęła uchwałe w sprawie wyboru prezydenta UE $i$ ministra spraw zagranicznych UE, http://www.lpr.pl/?sr=!czytaj\&id $=6750 \& \mathrm{dz}=\mathrm{kraj} \& \mathrm{x}=19 \&$ pocz $=0 \& \mathrm{gr}=(27.02 .2010)$.

${ }^{27}$ W obronie polskiej gospodarki, http://www.lpr.pl/?sr=!czytaj\&id=6563\&dz= kraj\&x $=4 \&$ pocz $=140 \& g r=(27.02 .2010)$. 
Ojczyzn, a więc integracji suwerennych państw i narodów na równych zasadach prawnych i ekonomicznych, opartej na współpracy i wartościach chrześcijańskich. Zasady owej integracji oraz współpracy proponuje się zapisać w Karcie Praw Wolnych Narodów Europy. Natomiast obecny kierunek integracji uważany jest za szkodliwy ze względu na biurokrację i deficyt demokracji. Zdaniem partii prowadzi on do osłabienia moralnego i ekonomicznego kontynentu oraz służy jedynie interesom najbogatszych członków Unii. Ponadto NP dostrzega w integracji europejskiej także zagrożenie germanizacją ziem zachodnich i północnych ${ }^{28}$.

Narodowe Odrodzenie Polski opowiada się za Europą narodów i suwerennych państw, pozbawionej ponadnarodowego i ponadpaństwowego zwierzchnictwa. Jest to Europa oparta na tradycyjnym chrześcijaństwie, jako jej podstawowym fundamencie cywilizacyjnym i etycznym, bez którego nie jest możliwa wolna i pokojowa egzystencja państw. W rozumieniu NOP nowoczesny nacjonalizm europejskich narodów winien szanować ich wolność, tym samym potępia jego zdaniem archaiczny i ograniczony nacjonalizm oparty na imperializmie i ekspansjonizmie. Unia Europejska jest „,chorym systemem”, który dąży do zniszczenia europejskich narodów. NOP w odpowiedzi na ten błędny w jego opinii charakter integracji europejskiej współpracuje z innymi podobnymi ugrupowaniami w ramach Europejskiego Frontu Narodowego. Te założenia przekładają się na radykalne postulaty programowe - NOP domaga się zakazu wszelkich działań oraz instytucji uprawiających ,prostytucję polityczną”, czyli opowiadających się za integracją europejskich, a więc zmierzające do „likwidacji Państwa Polskiego”. Ponadto NOP żąda zaprzestania integracji także z uwagi, iż nie są to stosunki oparte na partnerstwie, ale tylko takie partia ta popiera.

Jednoznacznie negatywna ocena Unii Europejskiej pojawia się także w programie Polskiej Wspólnoty Narodowej. Inicjatywa integracyjna jest wiązana z planami podboju Europy (od czasów Adolfa Hitlera) przez siły faszystowskie i imperialne. Obecny kształt Unii jest rozumiany jako dominacja Niemiec. UE jest postrzegana również jako zagrożenie dla bezpieczeństwa socjalnego. To ją obarcza się winą za negatywne skutki transformacji ekonomicznej (m.in. prywatyzację), oskarżając o celowe

28 DEKLARACJA IDEOWA RUCHU SPOEECZNEGO NAPRZÓD POLSKO, http://www.rs-naprzodpolsko.pl/page,0,0,deklaracja.html (27.02.2010); TEZY PROGRAMOWE RUCHU SPOEECZNEGO NAPRZÓD POLSKO, http://www.rs-naprzodpolsko.pl/page,0,0,naszprogram.html (27.02.2010). 
osłabianie państwa. Działania UE łączy się z działaniami Niemiec np. w kontekście przejmowania polskich mediów lub wykupywanie gruntów. Integrację z UE określa się jako czynienie z Polski „kolonii”, czemu ma służyć m.in. pogorszenie sytuacji w służbie zdrowia czy obniżenie poziomu oświaty. Jako alternatywę dla tych destrukcyjnych, zdaniem PWN, działań proponuje się odrzucenie działań integracyjnych i powołanie Wspólnoty Słowiańskiej, mającej zrównoważyć wpływy niemieckie ${ }^{29}$.

Również w programach innych partii o charakterze narodowym dominuje podobne podejście do kwestii integracji europejskiej. Narodowy Kongres Polski potępia wszelkiego rodzaju ograniczanie niepodległości na rzecz struktur ponadnarodowych. Pożądaną formą funkcjonowania UE jest ta zbliżona do EWG, natomiast projekt europejskiej Konstytucji jest postrzegany jako dążenie do likwidacji państw narodowych ${ }^{30}$.

Podobne zapisy znalazły się także w programie Polskiej Partii Narodowej, w którym odrzucono przekazywanie atrybutów suwerenności strukturom ponadnarodowym, a także kosmopolityzm. Opowiedziano się za Europą Wolnych Narodów, w której Polska ma być wolnym i silnym państwem, potępiając unijną biurokrację, politykę regionalizacji oraz marginalizację państwa polskiego ${ }^{31}$.

W programach wszystkich wymienionych partii pojawia się wyraźny krytycyzm w stosunku do Unii Europejskiej, a w szczególności do obecnego kierunku jej integracji (m.in. Traktat lizboński). Również samo członkostwo oceniane jest negatywnie. Często pojawia się pogląd, iż obecna integracja $\mathrm{w}$ rzeczywistości stanowi niemiecki plan podporządkowania sobie Europy, wykorzystywane są tutaj odwołania do historii XX wieku. Popieranym kierunkiem integracji jest Europa Narodów, oparta na współpracy suwerennych państw narodowych. Szczególnie silnie akcentowana jest potrzeba odwołania się do wartości chrześcijańskich i dorobku cywilizacji łacińskiej.

Spośród wielu partii o charakterze nacjonalistycznym jedynie Liga Polskich Rodzin zdołała uzyskać większe poparcie wyborcze, zwłaszcza w pierwszych latach swojej działalności. Szczytowe poparcie LPR uzyskała w pierwszych polskich wyborach do Parlamentu Europejskiego

29 B. Tejkowski, Unia Europejska zagraża Polsce, http://www.pwn.waw.pl/ (27.02.2010).

30 DEKLARACJA PROGRAMOWA Narodowego Kongresu Polskiego, 12.05.2007, s. $2-3$.

31 ZALOŻENIA PROGRAMOWE PPN, http://www.polskapartianarodowa.org/index.php?option=com_content\&task=view\&id=72\&Itemid=48 (28.02.2010). 
Wykres 7. Wyniki wyborcze (wybory parlamentarne i do Parlamentu Europejskiego)

Ligi Polskich Rodzin w latach 2001-2007

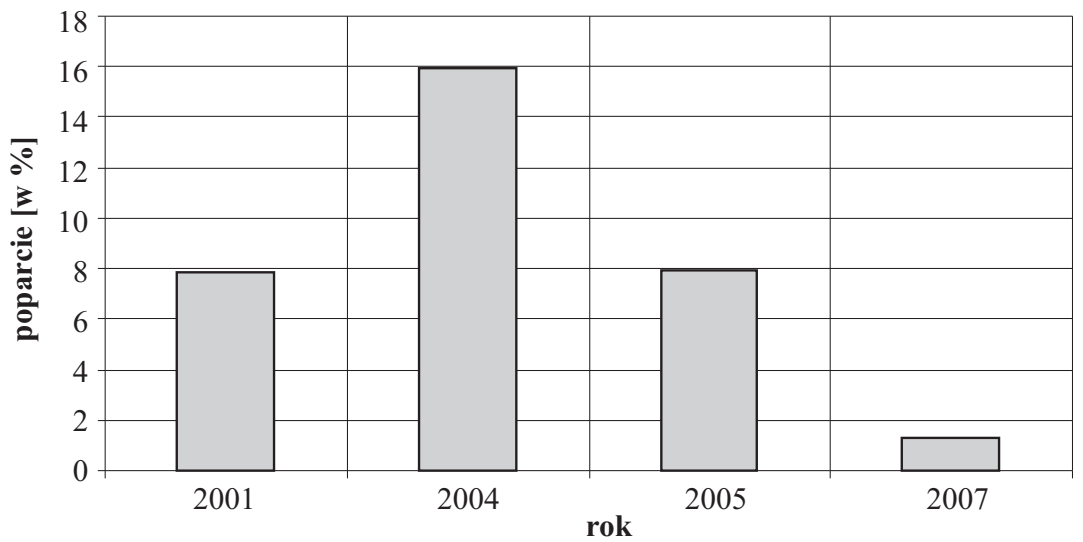

Źródlo: Państwowa Komisja Wyborcza, http://www.pkw.gov.pl/pkw2/index.jsp?place=Menu01\&news_cat_id=20\&layout=1 (26.02.2010).

w 2004 r., co mogło być wyrazem obaw części społeczeństwa związanych ze wstapieniem Polski do UE. W kolejnej kadencji Sejmu partia weszła w skład koalicji rządowej, jednak potem straciła poparcie społeczne.

\section{Wykres 8. Stosunek spoleczeństwa polskiego do czlonkostwa w Unii Europejskiej}

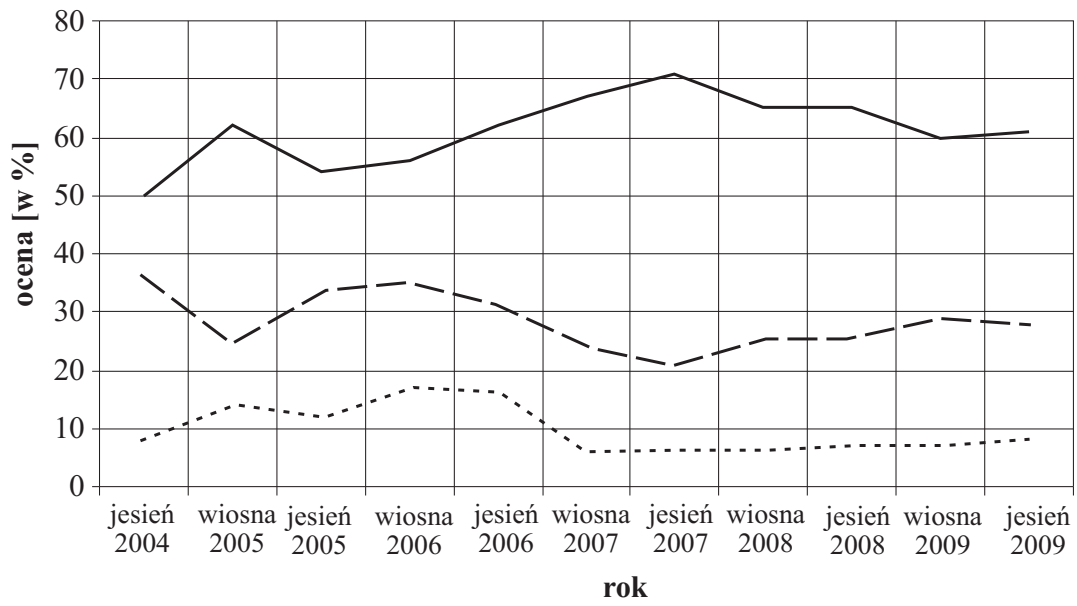

pozytywna _ - - ani pozytywna, ani negatywna $\quad . . .$. negatywna

Źródło: European Comission - Public Opinion, http://ec.europa.eu/public_opinion/standard_en.htm (23.02.2010). 
W następnych wyborach do PE kandydaci tej partii startowali z list ugrupowania Libertas, jednak również bez rezultatu. Antyeuropejska postawa LPR nie korespondowała z dużym (największym w Europie Środkowej) poparciem dla członkostwa w UE, co oznaczało, że jej program nie odpowiadał nastrojom społecznym.

\section{Wnioski}

Podsumowując powyższy przegląd programów politycznych partii nacjonalistycznych można zauważyć, iż we wszystkich pojawia się jedna, bardzo zbliżona wizja integracji europejskiej, jaką jest Europa Narodów, szanująca narodową tożsamość, której fundamentem są wolne i suwerenne państwa narodowe. Takie założenie zgodne jest z samą ideologią nacjonalizmu, w której to naród jest podstawą porządku społecznego, a państwo narodowe najwłaściwszą formą organizacji politycznej. Często podkreśla się też konieczność odwołania się do europejskich wartości (dorobku cywilizacji łacińskiej), w szczególności zaś do chrześcijaństwa, jako moralnej podstawy Europy. Czynnik cywilizacyjno-religijny wynika tutaj z jego szczególnego miejsca w kształtowaniu tożsamości narodowej, po części jest też wynikiem oddziaływania innych doktryn. Projekty federalistyczne są jednoznacznie krytykowane jako zagrażające właśnie państwu, a także wprowadzające dyktat większych państw. Zagrożenie powrotu do „koncertu mocarstw" na kontynencie europejskim, narzucaniu woli kilku państw innym, mniejszym podmiotom ma swoje uwarunkowania w historii regionu, także tej najnowszej. Ten wspólny element wynika zatem z podstawowych zasad nacjonalizmu i uznaniu narodu za nadrzędną wartość, dla której integracja europejska może być lub jest zagrożeniem.

Tym, co różnicuje powyższe programy lub jest charakterystyczne dla jednej lub kilku partii są pewne narodowe aspekty integracji. I tak w programach partii polskich i czeskich pojawia się obawa przed niemieckim rewizjonizmem, co wynika z doświadczeń historycznych, zwłaszcza stosunków tych państw z III Rzeszą. Szczególnie silne odwołania do katolicyzmu wśród polskich ugrupowań jest wynikiem włączenia pierwiastka religijnego do polskiego nacjonalizmu jeszcze w okresie międzywojennym. Słowacka SNS jako jedyna ma pozytywny stosunek do integracji, który jednak wynika z oceny położenia Słowacji w Europie. Węgierskich nacjonalistów, obok powszechnej obawy przed obcą dominacją, cechuje także negatywny stosunek do globalizacji, co jednak można uznać za za- 
grożenie podobne jak integracja europejska. Partie węierskie otaczają tradycyjnie troską Węgrów poza granicami ich państwa, co powoduje konflikt m.in. ze Słowakami. Można tutaj zauważyć pewną zbieżność programów polskich i czeskich, natomiast w przypadku ugrupowań słowackich i węgierskich widoczny jest silny konflikt. Te różnice przekładają się na ograniczone możliwości wzajemnej współpracy w europejskich organizacjach zrzeszających partie narodowe.

Poparcie, które ilustruje społeczny odbiór haseł nacjonalistycznych, również jest zróżnicowane w państwach regionu: od nikłego w Republice Czeskiej i w ostatnich latach w Polsce, po dość duże na Węgrzech (dopiero w ostatnich latach) oraz na Słowacji (od dłuższego czasu). Nie zawsze wyniki wyborcze przekładają się na poglądy dotyczące integracji europejskiej: nacjonalizm jest na ogół kojarzony z postawą skrajną, z tego też względu niepopularną. Natomiast podejście eurosceptyczne prezentują też znacznie większe partie konserwatywne i to one docierają do znacznie większej rzeszy społeczeństwa. Oznacza to, że partie nacjonalistyczne są nie tyle wyrazicielami sprzeciwu względem UE, lecz obrony narodu. Eurosceptycyzm jest tutaj jedynie elementem programu, nie zaś jego trzonem. $Z$ tego też względu nie można powiedzieć, że partie o orientacji narodowej wyrażają zawsze i w pełni obawy względem integracji europejskiej. Są natomiast miernikiem konfrontacji wciąż ewoluującej tożsamości narodowej z kreowaną obecnie tożsamością europejską i moga wyrażać znaczenie wartości, jaką stanowi naród.

\section{Summary}

The paper analyzes the attitude of nationalist parties in four Central European states (Poland, the Czech Republic, Slovakia and Hungary) to European integration. After 2004, some of them, e.g. the League of Polish Families (LPR), the Slovak National Party (SNS), and Jobbik in Hungary, gained parliamentary representation, or even entered governments thus obtaining some (albeit limited) influence on foreign policy. Their attitudes frequently expressed social fears and anxieties related to the accession to the EU. The integration process as such was assessed in different ways: from the demands to leave the Union and warnings that the states will lose their independence, to the approval of the Europe of nations concept, and the endorsement of EU membership. Their attitudes, contained in the political platforms of the parties, also reflected traditional antagonisms and the fear of neighbors and their policies (this mainly concerned the fear of all sorts of German and Hungarian revisionist claims), as well as their views on the influence of other subjects on the state's sovereignty and condition (including the frequent argument of excessive exploitation and threats to national possessions). 